\title{
POLYPHENOLOXIDASE ACTIVITY IN PEACHES AFTER VIBRATION
}

\author{
TIAGO B. H. DANTAS ${ }^{1}$, ANTÔNIO C. DE O. FERRAZ ${ }^{2}$, SYLVIO L. HONÓRIO², \\ GIUSEPPINA P. P. LIMA ${ }^{3}$
}

\begin{abstract}
The vibration during transportation is one of the main causes of fruit damage. The actual methodologies used for damage evaluation in fruits seem to be subjective, since most of them are based on visual evaluation. In this study the effect of vibration, for one and two hours, on polyphenoloxidase (PPO) activity in peach pulp was investigated. The relation among PPO activity variation, postharvest time and resting time were also considered. Results showed that vibration affects PPO activity. However, it was not possible to correlate PPO activity variation and vibration.
\end{abstract}

KEYWORDS: polyphenoloxidase, vibration, damage, peach.

\section{ATIVIDADE DE POLIFENOLOXIDASE EM PÊSSEGOS APÓS VIBRAÇÃO}

RESUMO: A vibração durante o transporte é uma das principais causas de dano em frutas. As metodologias atuais utilizadas na avaliação de danos em frutas parecem ser subjetivas, visto que a maioria delas é baseada em avaliações visuais. Neste trabalho, investigou-se o efeito da vibração em dois níveis, uma e duas horas, sobre a atividade de polifenoloxidase (PPO) em pêssegos. A relação entre a variação da atividade de PPO, tempo pós-colheita e tempo de repouso também foi considerada. Os resultados mostraram que a vibração afeta a atividade de PPO. Entretanto, não foi possível correlacionar a variação da atividade de PPO e a vibração.

PALAVRAS-CHAVE: polifenoloxidase, vibração, dano, pêssego.

\section{INTRODUCTION}

The occurrence of vibration damage during transportation of fruit and vegetables is always undesirable since it is related to losses in quality and reduction in shelf life. The mechanical plant tissue damage is a broad concept that embraces plastic deformation, superficial disruption such as cut, puncture and abrasion, and generalized vegetal tissue disruption, caused by external forces and leading to physical modifications and physiological, chemical and biological changes. From the point on view of quality, sensorial perception of color, flavor and firmness are taken into account by consumers (MOHSENIN, 1986).

Considering the importance of such losses and the need for better packaging design tools, many other investigations for agricultural products based on mechanical damages were performed in the last years, some of them focused on the product performance (BERARDINELLI et al., 2005; FERREIRA et al., 2006; GOMES, 2006; ZHOU et al., 2007; FERRAZ \& LACERDA, 2007; SANCHES et al., 2008; VALENTINI et al., 2009) and others focused on packaging design (CHONHENCHOB et al., 2008; JARIMOPAS et al., 2008; THOMPSON et al., 2008; ZHOU et al., 2008). They somewhat used conventional approaches either to investigate the response of the vegetable tissue solely or the produce-package system by evaluating changes in physical-chemical properties after a mechanical stress. Although these overall procedures have been widely used they often do not bring a better understanding to the damaging mechanism since the effect is measured as a combination of effects yielding to an overall response. Evaluations of these features also carry

\footnotetext{
${ }^{1}$ CETEA/ITAL - Packaging Technology Center of the Food Technology Institute, Av. Brasil, 2880, Campinas - SP, Brazil, tiago@ital.sp.gov.br.

${ }^{2}$ FEAGRI - School of Agricultural Engineering; University of Campinas - UNICAMP, Av. Cândido Rondon, 501, Campinas - SP, Brazil.

${ }^{3}$ IB/UNESP - Chemistry and Biochemistry Department of the São Paulo State University, Botucatu - SP, Brazil.

Recebido pelo Conselho Editorial em: 25-10-2010
}

Aprovado pelo Conselho Editorial em: 30-10-2012

Eng. Agríc., Jaboticabal, v.33, n.2, p.312-318, mar./abr. 2013 
certain subjectivity since they are mostly based on the appearance of the damaged portion or of the whole produce. In many cases, to obtain the full expression of such effects, a certain time is needed, making the processes time dependent and allowing the summing up of many different complex interactions to occur at various times. However, if prime vibration effect indicators could be identified, they could lead to better tissue evaluation since superposition effects could be reduced.

The investigation carried out by TOURINO et al. (1993) brings these arguments into evidence, since it was observed that peach fruits response to cut damages was detected as an increase in polyphenoloxidase (PPO) activity. Polyphenoloxidase (PPO) is one of the main enzymes related to enzymatic browning of phenolic compounds. Polyphenoloxidase may be considered universally distributed in plants, fungi and bacteria (MAYER, 2006). Although the PPO hole in plants biology is not completely clear, its produced reaction might indicate a defense mechanism (THIPYAPONG et al., 1995).

It is known to be present in peach fruit since long but the interest on the subject still continues (TOURINO et al., 1993; BRANDELLI \& LOPEZ, 2005; TORALLES et al., 2005). On the other hand, Bochu et al. (2001) and Yang et al. (2002) reported growth pattern changes in Gerbera jamesonii acrocarpous callus and Actinidia chinensis callus, respectively, as influenced by different mechanical vibration frequencies. Although the vibrations were not to the level of damaging the tissue, some frequencies altered the growth rate, the content of soluble protein and cell membrane fluidity. Combining these findings, it could be used the PPO activity response to evaluate vibration damages. PPO activity response was also chosen to investigate the effect of vibration on peach fruit because of its simplicity concerning the methodology and equipment availability. 'Douradão' peach was selected due to its high damage susceptibility (AMORIM et al., 2008), its importance in the state of São Paulo economy (ALMEIDA et al., 2005) and the proximity of our labs to the production site.

\section{MATERIAL AND METHODS}

\section{Peaches}

Ripe peaches (Prunus persica (L.) Batsch cv. Douradão) were hand-picked from a commercial orchard (Doni Frutas, in Jarinu, São Paulo, Brazil). The fruits were manually selected for absence of visual defects. Fruits were stored at 3-5 ${ }^{\circ} \mathrm{C}$ and $90-95 \%$ RH. After vibration, fruits were kept at lab conditions with temperature varying from 20 to $25^{\circ} \mathrm{C}$.

\section{Experimental design}

The experimental flow diagram is shown in Figure 1. Mechanical vibration was applied to the fruits in the $3^{\text {rd }}$ (PHT_3), $7^{\text {th }}$ (PHT_7), 11 ${ }^{\text {th }}$ (PHT_11) and 17 ${ }^{\text {th }}$ (PHT_17) days after harvest. Two vibration levels, one and two hours (vib_1h and vib_2h, respectively) of continuous vibration were chosen. Resting times (RT), corresponding to the time elapsed between the end of vibration and the PPO activity measurement, were taken as 1; 24 and 72 hours or, in short, RT_1, RT_24 and RT_72, respectively. The combination of these parameters resulted in 48 treatments. For each treatment, four peaches were evaluated. 


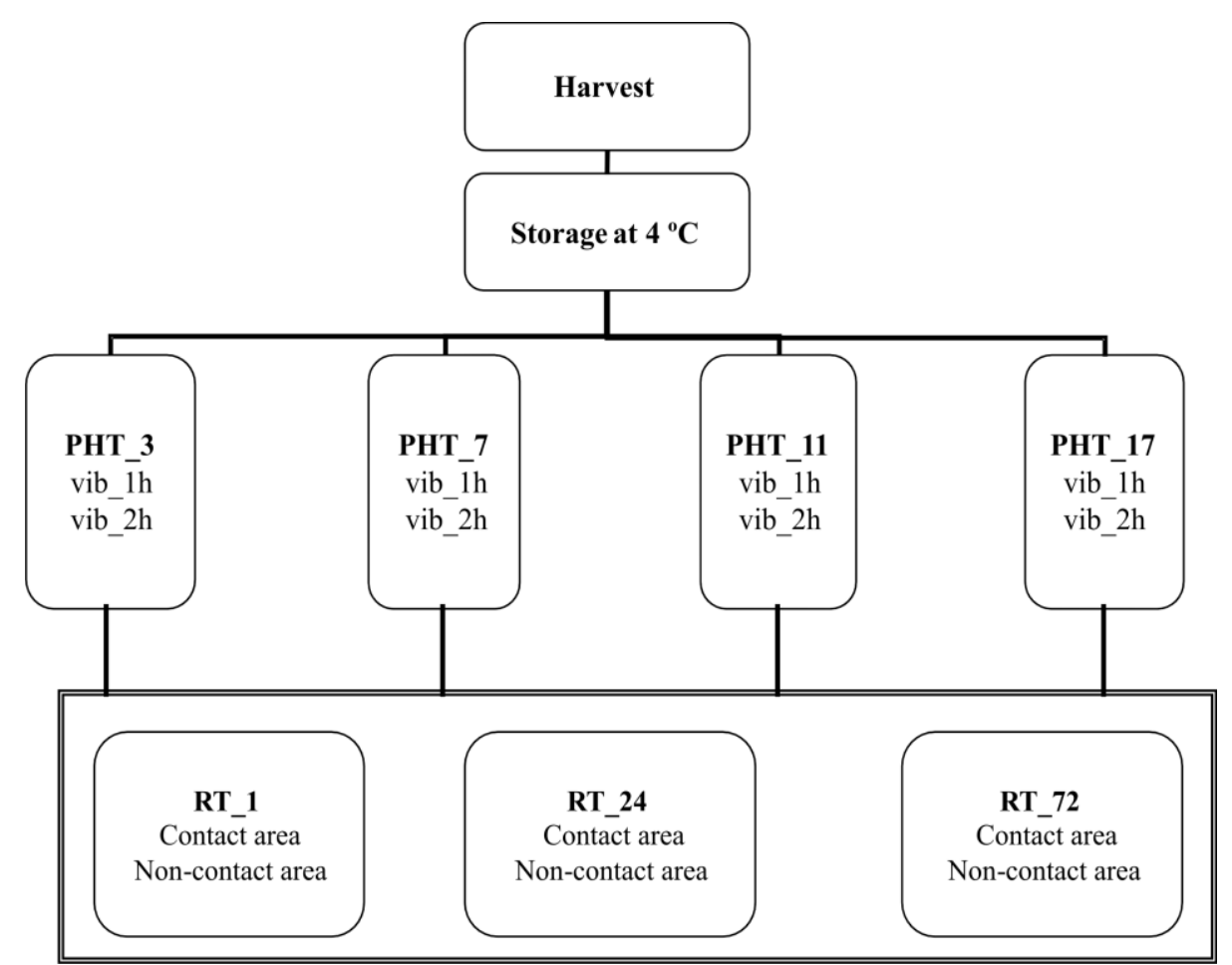

FIGURE 1. Experiment flow diagram.

\section{Vibration procedure}

Vibration tests were performed using a $1.5 \times 1.5 \mathrm{~m}, 5 \mathrm{t}$ of dynamic force vibration table (MTS, model 891). The table was automatically controlled (MTS, 407 Controller and SignalCalc 550 Vibration Controller) using an accelerometer (Kistler, model 8710A50M1), with resolution of $0.01 \mathrm{G}$.

Fruits were placed directly on the vibration table, kept still and subjected to a dwell vibration test at $5 \mathrm{~Hz}$, acceleration of $0.9 \mathrm{G}$ for 1 or 2 hours (18,000 and 36,000 cycles, respectively).

\section{Specimen removal}

After vibration tests, specimens were extracted from the fruit pulp. From each peach, two disk-like specimens were obtained, approximately $30 \mathrm{~mm}$ in diameter and $3 \mathrm{~mm}$ thickness; specimens were removed right from below the contact surface. Non-contact surface specimens were similarly extracted from the diametrically opposite region. Figure 2 illustrates the specimen removal regions. After removal, specimens were immediately sunk into liquid nitrogen and stored at -20 to $24{ }^{\circ} \mathrm{C}$.

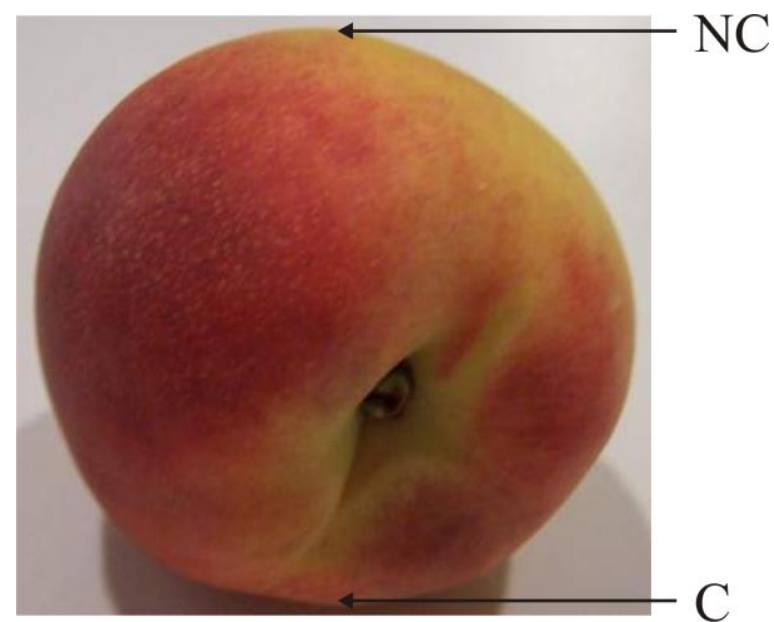

FIGURE 2. Illustration of specimen removal regions: C - contact area; NC - non-contact area. 


\section{Polyphenoloxidase assay}

Each frozen specimen sunk in liquid nitrogen was macerated until a homogeneous powder was obtained. From this material, $2 \mathrm{~g}$ were added to a centrifuge tube with $5 \mathrm{~mL}$ of buffer (sodium phosphate $0.05 \mathrm{M}, \mathrm{pH} 6.0)$ and kept in ice. The solution was centrifuged $(10,000 \mathrm{x} \mathrm{g}, 30 \mathrm{~min}$ at $4{ }^{\circ} \mathrm{C}$ ); the supernatant was filtered using organza cloth and a $0.5 \mathrm{~mL}$ from this were added to $3 \mathrm{~mL}$ of buffer and $0.1 \mathrm{~mL}$ of catechol $2 \mathrm{mM}$ (enzyme substrate). The following reaction was conducted at $30{ }^{\circ} \mathrm{C}$ for 30 minutes, and ceased using a 5 minutes boiling water-bath. Tubes were placed in an ice bath until reaching room temperature and the solution absorbance was measured at $420 \mathrm{~nm}$ using an Ultrospec 2000 spectrophotometer (Pharmacia Biotech). PPO activity was expressed in $\mu \mathrm{mol}$ of degraded catechol $\cdot \mathrm{min}^{-1} \cdot \mathrm{g}$ of fresh mass $^{-1}$ (adapted from Cano et al., 1997). Absorbance determinations were made in duplicate, except for PHT_3 specimens in which just one absorbance determination was done.

\section{RESULTS AND DISCUSSION}

The average results for PPO activity are shown in Figure 3 and they indicate a tendency of increasing activity variation along postharvest time but specially with resting time. The 72 hours resting time showed the highest PPO activity variation.

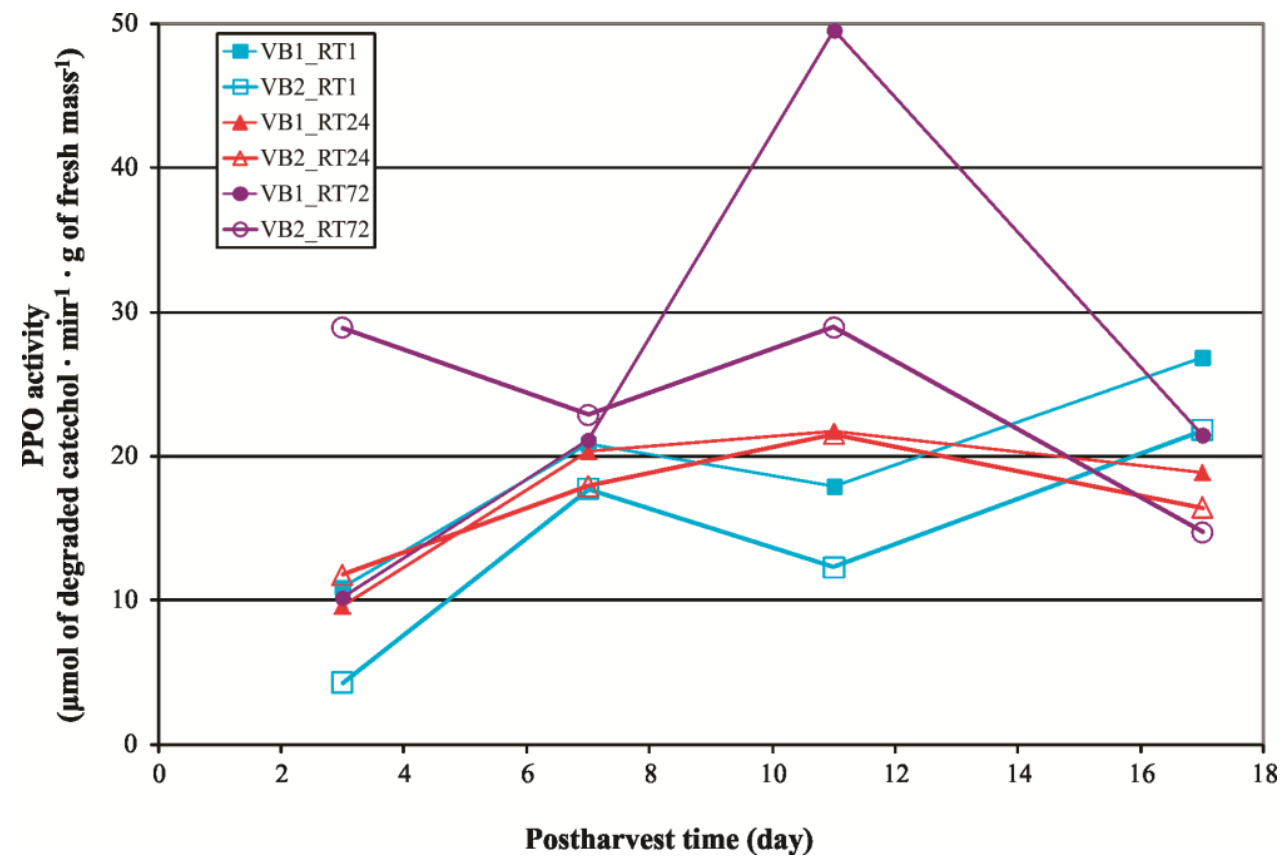

FIGURE 3. Average PPO activity in contact area specimens along postharvest time $\left(\mathrm{VB}+\mathrm{n}^{\mathrm{o}}=\right.$ vibration time; $\mathrm{TR}+\mathrm{n}^{\mathrm{o}}=$ resting time).

Tables 1 to 4 show the results for all treatments including resting and vibration times, PPO activity (expressed in $\mu \mathrm{mol}$ of degraded catechol $\cdot \mathrm{min}^{-1} \cdot \mathrm{g}$ of fresh mass ${ }^{-1}$ ) with corresponding coefficient of variation and the PPO activity variation $(\%)$ corresponding to the contact area to the non-contact area ratio of the same peach. The PPO activity values refer to the mean results from four peaches. Comparing PPO activity variation for the four postharvest times and each resting time (Tables 1 to 4), higher values for higher vibration time only occurred twice, at PHT_3, RT_24 with values of $23.1 \%$ and $40.5 \%$, and at PHT_17, RT_24 with values of $8.6 \%$ and $13.9 \%$, respectively. The other treatments showed higher values for lower vibration times. These results also indicated that for the majority of treatments PPO activity was not correlated to mechanical vibration time. However, one has to consider the high coefficients of variation obtained, up to $45 \%$, indicating that those differences in average values may not be of any practical value. 
TABLE 1. PPO activity variation in peaches submitted to mechanical vibration on $3^{\text {rd }}$ postharvest day (PHT_3).

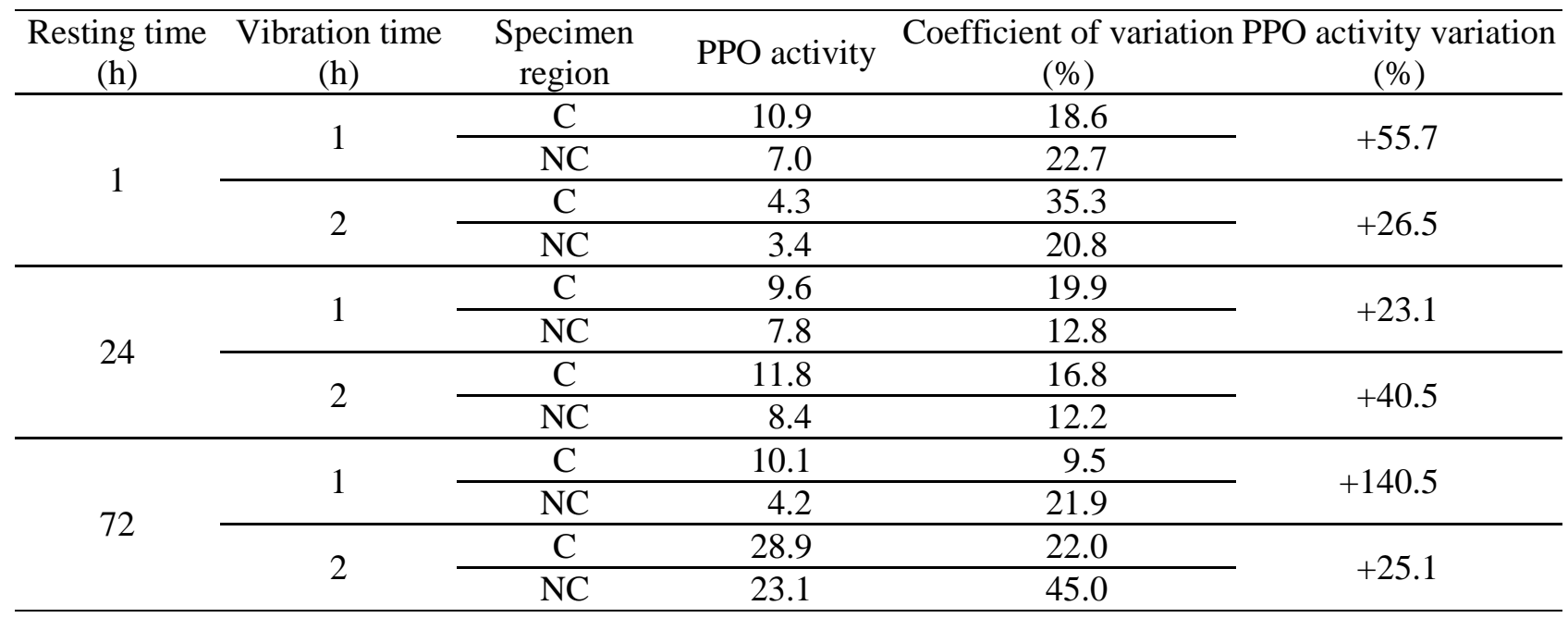

TABLE 2. PPO activity variation in peaches submitted to mechanical vibration on $7^{\text {th }}$ postharvest day (PHT_7).

\begin{tabular}{|c|c|c|c|c|c|}
\hline $\begin{array}{l}\text { Resting time } \\
\text { (h) }\end{array}$ & Vibration time & $\begin{array}{l}\text { Specimen } \\
\text { region }\end{array}$ & PPO activity & $\begin{array}{c}\text { Coefficient of variation } \\
(\%)\end{array}$ & $\begin{array}{l}\text { PPO activity variation } \\
(\%)\end{array}$ \\
\hline \multirow{4}{*}{1} & \multirow{2}{*}{1} & $\mathrm{C}$ & 20.9 & 9.8 & \multirow{2}{*}{-1.4} \\
\hline & & $\mathrm{NC}$ & 21.2 & 11.6 & \\
\hline & \multirow[b]{2}{*}{2} & $\mathrm{C}$ & 17.7 & 12.6 & \multirow{2}{*}{-20.3} \\
\hline & & $\mathrm{NC}$ & 22.2 & 15.3 & \\
\hline \multirow{4}{*}{24} & \multirow{2}{*}{1} & $\mathrm{C}$ & 20.4 & 8.6 & \multirow{2}{*}{-11.3} \\
\hline & & $\mathrm{NC}$ & 23.0 & 16.1 & \\
\hline & \multirow{2}{*}{2} & $\mathrm{C}$ & 17.9 & 15.2 & \multirow{2}{*}{-14.4} \\
\hline & & $\mathrm{NC}$ & 20.9 & 19.3 & \\
\hline \multirow{4}{*}{72} & \multirow{2}{*}{1} & $\mathrm{C}$ & 21.1 & 17.0 & \multirow{2}{*}{+28.7} \\
\hline & & $\mathrm{NC}$ & 16.4 & 17.6 & \\
\hline & \multirow{2}{*}{2} & $\mathrm{C}$ & 22.9 & 12.8 & \multirow{2}{*}{+23.1} \\
\hline & & $\mathrm{NC}$ & 18.6 & 11.7 & \\
\hline
\end{tabular}

TABLE 3. PPO activity variation in peaches submitted to mechanical vibration on $11^{\text {th }}$ postharvest day (PHT_11).

\begin{tabular}{|c|c|c|c|c|c|}
\hline $\begin{array}{l}\text { Resting time } \\
\text { (h) }\end{array}$ & Vibration time & $\begin{array}{l}\text { Specimen } \\
\text { region }\end{array}$ & PPO activity & $\begin{array}{c}\text { Coefficient of variation } \\
(\%)\end{array}$ & $\begin{array}{c}\text { PPO activity variation } \\
(\%)\end{array}$ \\
\hline \multirow{4}{*}{1} & \multirow{2}{*}{1} & $\mathrm{C}$ & 17.9 & 14.9 & \multirow{2}{*}{-3.2} \\
\hline & & $\mathrm{NC}$ & 18.5 & 15.4 & \\
\hline & \multirow{2}{*}{2} & $\mathrm{C}$ & 12.3 & 11.3 & \multirow{2}{*}{-56.7} \\
\hline & & $\mathrm{NC}$ & 28.4 & 12.2 & \\
\hline \multirow{4}{*}{24} & \multirow{2}{*}{1} & $\mathrm{C}$ & 21.7 & 25.8 & \multirow{2}{*}{+40.9} \\
\hline & & $\mathrm{NC}$ & 15.4 & 40.1 & \\
\hline & \multirow{2}{*}{2} & $\mathrm{C}$ & 21.5 & 16.7 & \multirow{2}{*}{+15.6} \\
\hline & & $\mathrm{NC}$ & 18.6 & 11.8 & \\
\hline \multirow{4}{*}{72} & \multirow[b]{2}{*}{1} & $\mathrm{C}$ & 49.6 & 4.4 & \multirow{2}{*}{+157.0} \\
\hline & & $\mathrm{NC}$ & 19.3 & 14.3 & \\
\hline & \multirow{2}{*}{2} & $\mathrm{C}$ & 20.9 & 8.4 & \multirow{2}{*}{-34.9} \\
\hline & & $\mathrm{NC}$ & 32.1 & 11.3 & \\
\hline
\end{tabular}


TABLE 4. PPO activity variation in peaches submitted to mechanical vibration on $17^{\text {th }}$ postharvest day (PHT_17).

\begin{tabular}{|c|c|c|c|c|c|}
\hline $\begin{array}{l}\text { Resting time } \\
\text { (h) }\end{array}$ & Vibration time & $\begin{array}{l}\text { Specimen } \\
\text { region }\end{array}$ & PPO activity & $\begin{array}{c}\text { Coefficient of variation } \\
(\%)\end{array}$ & $\begin{array}{c}\text { PPO activity variation } \\
(\%)\end{array}$ \\
\hline \multirow{4}{*}{1} & \multirow{2}{*}{1} & $\mathrm{C}$ & 26.9 & 5.5 & \multirow{2}{*}{+74.7} \\
\hline & & $\overline{\mathrm{NC}}$ & 15.4 & 6.6 & \\
\hline & \multirow{2}{*}{2} & $\mathrm{C}$ & 21.8 & 6.7 & \multirow{2}{*}{+30.5} \\
\hline & & $\mathrm{NC}$ & 16.7 & 10.6 & \\
\hline \multirow{4}{*}{24} & \multirow{2}{*}{1} & $\mathrm{C}$ & 18.9 & 9.8 & \multirow{2}{*}{+8.6} \\
\hline & & $\mathrm{NC}$ & 17.4 & 37.0 & \\
\hline & \multirow{2}{*}{2} & $\mathrm{C}$ & 16.4 & 33.3 & \multirow{2}{*}{+13.9} \\
\hline & & $\mathrm{NC}$ & 14.4 & 35.1 & \\
\hline \multirow{4}{*}{72} & \multirow{2}{*}{1} & $\mathrm{C}$ & 21.5 & 23.7 & \multirow{2}{*}{+41.4} \\
\hline & & $\mathrm{NC}$ & 15.2 & 21.3 & \\
\hline & \multirow{2}{*}{2} & $\mathrm{C}$ & 14.7 & 17.8 & \multirow{2}{*}{+34.9} \\
\hline & & $\mathrm{NC}$ & 10.9 & 21.2 & \\
\hline
\end{tabular}

In almost $30 \%$ of the treatments (7 from 24 observations) it was observed that PPO activity variation was negative, i.e. PPO activity was higher on the non-contact area. This occurrence may be explained by the enzyme distribution throughout the fruit, which may not be homogeneous. Another possibility is that mechanical vibration did not act on the contact area alone, but its effect was spread along the whole fruit. This could affect the calculated PPO activity variation values, since it depends on the contact and non-contact areas PPO activity measurements.

\section{CONCLUSIONS}

PPO activity variations in peaches due to mechanical vibration were detected. However, it was not possible to establish a correlation between the vibration level and enzyme activity regarding the methodology. Based on this and on the high coefficients of variation found, it seems necessary a methodological refinement.

\section{REFERENCES}

ALMEIDA, G. V. B.; MANCO, J. R.; SAKABE, M. Mercado atacadista de frutas de caroço e suas exigências. In: CALEGARIO, F. F. Padronização e classificação de pêssegos e nectarinas. Bento Gonçalves: Embrapa Uva e Vinho, 2005. p.19-29.

AMORIM, L. MARTINS, M. C.; LOURENÇO, S. A.; GUTIERREZ, A. S. D.; ABREU, F. M.; GONÇALVES, F. P. Stone fruit injuries and damage at the wholesale market of São Paulo, Brazil. Postharvest Biology and Technology, Amsterdam, v.47, n.3, p.353-357, 2008.

BERARDINELLI, A. DONATI, V.; GIUNCHI, A.; GUARNIERI, A.; RAGNI, L. Damage to pears caused by simulated transport. Journal of Food Engineering, Essex, v.66, n.2, p.219-226, 2005.

BOCHU, W.; XUEFENG, L.; YIYAO, L.; SAKANISHI, A. Response of gerbera jamesonii acrocarpous callus stimulated by mechanical vibration. Colloids and Surfaces B: Biointerfaces, Amsterdam, v.21, n.4, p.253-257, 2001.

BRANDELLI, A.; LOPES, C. H. G. L. Polyphenoloxidase activity, browning potential and phenolic content of peaches during postharvest ripening. Journal of Food Biochemistry, Westport, v.29, n.6, p.624-637, 2005.

CANO, M. P.; HERNANDEZ, A.; DE ANCOS, B. High pressure and temperature effects on enzyme inactivation in strawberry and orange products. Journal of Food Science, Chicago, v.62, n.1, p.85-88, 1997. 
CHONHENCHOB, V.; KAMHANGWONG, D.; SINGH, S. P. Comparison of reusable and singleuse plastic and paper shipping containers for distribution of fresh pineapples. Packaging Technology and Science, Inglaterra, v.21, n.2, p.73-83, 2008.

FERRAZ, A. C. O.; LACERDA, F. C. Frequências durante o transporte afetam diferencialmente a aparência do figo Roxo de Valinhos. In: CONGRESSO IBEROAMERICANO DE TECNOLOGIA POSTCOSECHA Y AGROEXPORTACIONES, 5., 2007, Anais... p.1310-1319.

FERREIRA, M. D.; CORTEZ L. A. B.; HONÓRIO, S. L.; TAVARES, M. Avaliação física do tomate de mesa 'Romana' durante manuseio na pós-colheita. Engenharia Agrícola, Jaboticabal, 2006, v.26, n.1, p.321-327.

GOMES, D. Efeitos da vibração na qualidade da uva 'Niagara rosada'. 2006. 84f. Dissertação (Mestrado em Engenharia Agrícola) - Faculdade de Engenharia Agrícola, Universidade Estadual de Campinas, 2006.

JARIMOPAS, B.; RACHANUKROA, D.; SINGH, S. P.; SOTHORNVIT, R. Post-harvest damage and performance comparison of sweet tamarind packaging. Journal of Food Engineering, Essex, v.88, p.193-201, 2008.

MAYER, A. Polyphenol oxidases in plants and fungi: going places? A review. Phytochemistry, New York, v.67, n.21, p.2318-2331, 2006.

MOHSENIN, N. N. Physical properties of plant and animal materials: structure, physical characteristics and mechanical properties. 2nd. ed. New York: Gordon and Breach, 1986. 891 p.

SANCHES, J.; DURIGAN, J. F.; DURIGAN, M. F. B. Aplicação de danos mecânicos em abacates e seus efeitos na qualidade dos frutos. Engenharia Agrícola, Jaboticabal, v.28, n.1, p.164-175, 2008

THIPYAPONG, P.; HUNT, M. D.; STEFFENS, J. C. Systemic wound induction of potato (Solanum tuberosum) polyphenol oxidase. Phytochemistry, New York, v.40, n.3, p.673-676, 1995.

THOMPSON, J. F.; SLAUGHTER, D. C.; ARPAIA, M. L. Suspended tray package for protecting soft fruit from mechanical damage. Applied Engineering in Agriculture, St. Joseph, v.24, n.1, p.71$75,2008$.

TORAllES, R. P.; VENDRUSCOLO, J. L.; VENDRUSCOLO, C. T.; DEL PINO, F. A. B.; ANTUNES, P. L. Properties of polyphenoloxidase and peroxidase from 'Granada' clingstone peaches. Brazilian Journal of Food Technology, Campinas, v.8, n.3, p.233-242, 2005.

TOURINO, M. C. C.; CHITARRA, A. B., GAVILANES, M. C.Injúria mecânica em tecidos de frutos de pessegueiros (Prununs persica (L.) Batsch): mecanismos de cura. Boletim da Sociedade Brasileira de Ciência e Tecnologia de Alimentos, Campinas, v.27, n.2, p.69-78, 1993.

VALENTINI, S. R. T.; FERREIRA, M. D.; ATARASSI, M. E.; BENATO, E. A. Avaliação de linhas de beneficiamento e impactos de queda na qualidade de caqui "Rama Forte". Engenharia Agrícola, Jaboticabal, v.29, n.4, p.642-655, 2009.

YANG, X. C.; WANG, B. C.; LIU, Y. Y.; DUAN, C. R.; DAI, C. Y. Biological effects of Actinidia chinensis callus on mechanical vibration. Colloids and Surfaces B: Biointerfaces, Amsterdam, v.25, n.3, p.197-203, 2002.

ZHOU, R.; SU, S.; YAN, L.; LI, Y. Effect of transport vibration levels on mechanical damage and physiological responses of Huanghua pears (Pyrus pyrifolia Nakai, cv. Huanghua). Postharvest Biology and Technology, Amsterdam v.46, n.1, p.20-28, 2007.

ZHOU, R.; SU, S., LI, Y. Effects of cushioning materials on the firmness of Huanghua pears (Pyrus pyrifolia Nakai cv. Huanghua) during distribution and storage. Packaging Technology and Science, New York, v.21, n.1, p.1-11, 2008. 